American Journal of Applied Sciences 8 (7): 703-707, 2011

ISSN 1546-9239

(C) 2011 Science Publications

\title{
Performance and its Link to Entrepreneurial Behavior
}

\author{
${ }^{1}$ Kuo-Hsiung Chen, ${ }^{2}$ Jui-Mei Yien, ${ }^{3}$ Kai-Ping Huang and ${ }^{4}$ Chien-Jung Huang \\ ${ }^{1}$ Department of Business Administration, Cheng Shiu University, Taiwan \\ ${ }^{2}$ Department of Leisure Management, University of Kang Ning, Taiwan \\ ${ }^{3}$ School of Management, University of Technology, Sydney, Australia \\ ${ }^{4}$ Department of Marketing and Distribution Management, \\ Fortune Institute of Technology, Taiwan
}

\begin{abstract}
Problem statement: This study investigates the effects of Entrepreneurial Orientation (EO) on firm performance. In recent times, especially with the growth of globalization and other such factors, the performance measurement standards and parameters have changed. This has also led to a significant change in the factors that are now used within the operational sphere of an organization in order to affect the firm performance. Approach: The literature review illustrates the relationship between EO and firm performance. Results: Firms with high levels of EO tend to enhance firms' abilities find new opportunities and increase their competitive advantage. Conclusion: Although research has shown a fairly consistent positive relationship between EO and firm performance, there has been limited research on the mechanisms that might moderate the influence of EO on firm performance.
\end{abstract}

Key words: Entrepreneurial orientation, firm performance, risk-taking, innovativeness, managerial vision, strategic management, various elements

\section{INTRODUCTION}

The organization, in the modern day context, has become a body that is made up of its human resource and the quality that this resource base imbibes into the operational sphere of the organization. The modern day organization depends to a great extent on the contribution and quality of its human capital. The human capital may be defined as that element of the organization's operational sphere that is a living, breathing part of the activities that put the innate resources and factors of production into application. This application results in profits arising out of the activities of the human capital and the efficiency with which this resource carries out its tasks. This in turn, has a bearing on the achievement of the organization's goals in the sense that the organization is structured according to the quality of the human resource within it. Also, it shows the principles that are followed by the management in manning the organization. The study aims to investigate the entrepreneurial orientation and performance relationship. Future research directions regarding this relationship are also provided.

\section{MATERIALS AND METHODS}

Entrepreneurship is a topic that has been widely discussed to date (Lumpkin and Dess, 1996; Dess et al.,
1997; Lumpkin and Dess, 2001; Baker and Sinkula, 2009; Soriano and Dobon, 2009; Kuratko and Audretsch., 2009). Nonetheless, because of the changing focus of entrepreneurship, there is still no common definition for it. In early research, entrepreneurship was associated with great men with an innate ability to bring "new" combinations to the market (Schumpeter, 1982). Later research was mainly aimed at discovering the specific characteristics of entrepreneurial individuals such as an internal locus of control (Begley and Boyd, 1987). However, after limited success in identifying the key characteristics of entrepreneurs, the focus turned to the study of entrepreneurial behavior and processes in the organization. As Gartner (1988) has argued, the focus should be on what entrepreneurs do in the organization rather than on what they are.

The term 'entrepreneurial orientation' has been used to refer to the strategy-making processes and styles adopted by firms in their entrepreneurial activities (Lumpkin and Dess, 1996; Lumpkin and Dess, 2001). Miller (1983) considers that an entrepreneurial firm is one that engages in product market innovation, undertakes risky ventures and is the first firm to come up with 'proactive' innovations ahead of competitors. Following Miller's definition, numerous scholars have adopted the term 'entrepreneurial 
orientation' to describe a fairly consistent set of related activities or processes (Morris and Paul, 1987). Although Lumpkin and Dess (1996) consider entrepreneurial orientation to have five dimensions, there is widespread agreement amongst researchers that this construct has three core dimensions: innovativeness, proactiveness and risk-taking (Hughes and Morgan, 2007; Wiklund and Shepherd, 2005; Zahra 1991; Miller 1983). Although these three dimensions may vary independently of one another (Lumpkin and Dess, 2001; Wiklund and Shepherd, 2005, Hughes and Morgan, 2007; Rauch et al., 2009), entrepreneurial orientation will be regarded as a combination of innovativeness, proactiveness and risk-taking in the proposed study. Innovativeness is a firm's ability to conceive and implement new ideas and methods that may result in new products, services or processes (Li et al., 2008). It implies willingness to support creativity and experimentation. Proactiveness is an insight into the likelihood of a future action that leads to anticipation and action. In the marketplace it can generate a first-mover advantage vis-à-vis competitors (Lumpkin and Dess, 2001). Proactive firms look to what may well be about to happen and are thus able to capitalize on emerging opportunities (Chow, 2006; Keh et al., 2007).

\section{RESULTS}

The literature treats entrepreneurial orientation as a construct that differs from entrepreneurship itself. Entrepreneurship generally refers to new entries in markets (Mantell, 2009; Lee et al., 2001). Entrepreneurial orientation, on the other hand, is related to the entrepreneurial process and Furthermore, entrepreneurial orientation results in the destruction of old business practice stereotypes and the establishment of new, innovative, risk-tolerating patterns of economic behavior.

There is also reason to believe that entrepreneurial orientation can have positive performance implications that are universal. A general tendency in today's business environment is the shortening of product and business model life cycles (Lillis and Tian, 2010; Hamel, 2002). Future profit streams from existing operations are consequently uncertain and businesses need to maintain a search for new opportunities. Several empirical studies find support for the view that entrepreneurial orientation has a positive impact on performance (Wiklund, 1999; Zahra, 1991; Zahra and Covin, 1995; Tang et al., 2007; 2008; Keh et al., 2007; Rauch et al., 2009; Lusk et al., 2010), and anecdotal evidence supporting the value of entrepreneurship abounds (Hamel, 2002). In other words, entrepreneurial orientation plays an important role in organizational success and leads to better firm performance.

\section{CONCLUSION}

Previous research has shown a fairly consistent positive relationship between EO and firm performance. Studies aimed at understanding this relationship have primarily focused on the analysis of the separate dimensions of EO (Lumpkin and Dess, 1996; Hughes and Morgan, 2007) or on the isolation of contingency variables that moderate this relationship. These moderating variables include environmental factors (Lumpkin and Dess, 1996; Chow, 2006; Alexandrova, 2004), social network factors (Madsen, 2007; Stam and Elfring, 2006) and resource factors (Wiklund and Shepherds, 2005; Keh et al., 2007). However, to date there has been limited integrated research on the mechanism through which these factors might moderate the relationship between EO and firm performance.

Further, research on the influence of EO on firm performance has usually focused on large enterprises (Zahra, 1996). Despite the importance of small and medium-sized enterprises (SMEs) for most of the world's economies, a very limited number of studies have investigated the influence of EO on SME performance (Salavou and Lioukas, 2003; Wiklund and Shepherd, 2005) and the underlying causes of this relationship in SMEs have gone largely unexplored.

Future research would also focus on the effects of social capital on the EO and SMEs relationship. Research has shown that one of the important advantages of social networks is an increased ability to acquire valuable resources (Knoke, 2009; Chisholm and Nielsen, 2009; Francis et al., 2009; Runyan et al., 2007; Tsai, 2000; Barney, 1991; Nahapiet and Ghoshal, 1998; Gulati, 1999). The resource acquisition benefits derived from a social network are important for SMEs because they can help firms to overcome market information hurdles and develop new capabilities in an efficient manner. Gulati and Gargiulo (1999) note that social networks are an important intelligence web for SMEs in that they allow participants to share resources through network exchange activities. Social networks may offer an efficient means for firms to overcome deficiencies in their organizational capabilities. Jarillo (1995) points out that firm in a network can specialize in value chain activities that are essential to their competitive advantages (AL-Shubiri, 2010). By specializing in a specific part of the value chain that serves a number of 
customers, SMEs can achieve scale economies to a certain degree in spite of their size disadvantage. Finally, it has been recognized that long-term relationships SMEs form with network partners offer strategic benefits because they provide direct and indirect access to key resources, skills and knowledge controlled by other members within the network (Tan $e t$ al., 2011; Roy et al., 2004). Such resource advantages are sustainable because they are difficult for firms outside the network to appropriate or copy.

\section{REFERENCES}

Alexandrova, M., 2004. Entrepreneurship in a transition economy: The impact of environment on entrepreneurial orientation. Prob. Perspectives Manage., $\quad 2$ 140-148. http://www.businessperspectives.org/journals_free/ ppm/2004/ppm_en_2004_02_Alexandrova.pdf

AL-Shubiri, F.N., 2010. Analysis the determinants of corporate philanthropy: A case study in the Jordanian commercial banks. J. Soc. Sci., 6: 244251. DOI: $10.3844 /$ jssp.2010.244.251

Baker, W.E. and J.M. Sinkula, 2009. The complementary effects of market orientation and entrepreneurial orientation on profitability in small businesses. J. Small Bus. Manage., 47: 443-464. DOI: $10.1111 / \mathrm{j} .1540-627 X .2009 .00278 . \mathrm{X}$

Barney, J.B., 1991. Firm resources and sustained competitive advantage. J. Manage., 17: 99-120. DOI: $10.1177 / 014920639101700108$

Begley, T.M. and D.P. Boyd, 1987. Psychological characteristics associated with performance in entrepreneurial firms and smaller businesses. J. Bus. Ventur., 2: 79-93. DOI: 10.1016/08839026(87)90020-6

Chisholm, A.M., and K. Nielsen, 2009. Social capital and the resource-based view of the firm. Int. Stud. Manage. Org., 39: 7-32. DOI: 10.2753/IMO00208825390201

Chow, I.H., 2006. The relationship between entrepreneurial orientation and firm performance in China. SAM Adv. Manage. J., 71: 11-20. http://findarticles.com/p/articles/mi_hb6698/is_3_7 1/ai_n29301192/

Dess, G.G., G.T. Lumpkin, and J.G. Covin, 1997. Entrepreneurial strategy making and firm performance: Tests of contingency and configurational models. Strategic Manage. J., 18: 667-695.

DOI: $10.1002 /(\mathrm{SICI}) 1097-$ 0266(199710)18:9<677::AID-SMJ905>3.0.CO;2-Q
Francis, J., A. Mukherji, and J. Mukherji, 2009. Examining relational and resource influences on the performance of border region SMEs. Int. Bus. Rev., $\quad 18$ : 331-343. 10.1016/j.ibusrev.2009.04.004

Gartner, W.B., 1988. Who is an entrepreneur? Is the wrong question. Am. J. Small Bus., 12: 11-32. http://papers.ssrn.com/sol3/papers.cfm?abstract_id $=1505236$

Gulati, R., 1999. Network location and learning: the influence of network resources and firm capabilities on alliance formation. Strategic Manage. J., 20: 397-420. DOI: 10.1002/(SICI)1097-0266(199905)20:5<397::AIDSMJ35>3.0.CO;2-K

Gulati, R., and M. Gargiulo, 1999. Where do interorganizational networks come from? Am. J. Sociol., 104: 177-231. DOI: 10.2307/2990941

Hamel, G., 2002. Leading the Revolution. Harvard University Press, Cambridge, MA,. ISBN-13: 9781591391463, pp: 336.

Hughes, M. and R.E. Morgan, 2007. Deconstructing the relationship between entrepreneurial orientation and business performance at the embryonic stage of firm growth. Indus. Market. Manage., 36: 651661. DOI: 10.1016/j.indmarman.2006.04.003

Jarillo, J.C., 1995. Strategic Networks: Creating the Borderless Organization. Butterworth-Heinemann, Oxford, ISBN-10: 0750623276, pp: 178.

Keh, H.T., T.T.M. Nguyen, and H.P. Ng, 2007. The effects of entrepreneurial orientation and marketing information on the performance of SMEs. J. Bus. Ventur., 22: 592-611. DOI: 10.1016/j.jbusvent.2006.05.003

Knoke, D., 2009. Playing well together: Creating corporate social capital in strategic alliance networks. Am. Behav. Sci., 52: 1690-1708. DOI: 10.1177/0002764209331533

Kuratko, D.F. and D.B. Audretsch, 2009. Strategic entrepreneurship: Exploring different perspectives of an emerging concept. Entrepreneurship: Theory Practice, 33: 1-17. DOI: 10.1111/j.15406520.2008.00278.x

Lee, C., K. Lee, and J.M. Pennings, 2001. Internal capabilities, external network, and performance: A study on technology-based ventures. Strategic Manage. J., 22: 615-640. DOI: 10.1002/smj.181

Li, Y., Y. Zhao, J. Tan, and Y. Liu, 2008. Moderating effects of entrepreneurial orientation on market orientation-performance linkage: Evidence from Chinese small firms. J. Small Bus. Manage., 46: 113-133.DOI: 10.1111/j.1540-627X.2007.00235.x 
Lillis, M.P. and R.G. Tian, 2010. Cultural issues in the business world: An anthropological perspective. J. Soc. Sci., 6: 99-112. DOI: 10.3844/jssp.2010.99.112

Lumpkin, G.T. and G.G. Dess, 1996. Clarifying the entrepreneurial orientation construct and linking it to performance. Acad. Manage. Rev., 21: 135-172. DOI: $10.2307 / 258632$

Lumpkin, G.T. and G.G. Dess, 2001. Linking two dimensions of entrepreneurial orientation to firm performance: The moderating role of environment and industry life cycle. J. Bus. Ventur., 16: 429451. DOI: 10.1016/S0883-9026(00)00048-3

Lusk, E.J., M. Halperin, A. Tetikov, and N. Stefanova, 2010. Forecasting financial market annual performance measures: Further evidence. Am. J. Econ. Bus. Admin., 2: 300-306. DOI: 10.3844/ajebasp.2010.300.306

Madsen, E.L., 2007. The significance of sustained entrepreneurial orientation on performance firms-A longitudinal analysis. Entrepreneurship Reg. Dev., 19: 185-204. DOI: 10.1080/08985620601136812

Mantell, E.H., 2009. A theory of the risks of venture capital financing. Am. J. Econ. Bus. Admin., 1: 194-205. DOI: 10.3844/ajebasp.2009.194.205

Miller, D., 1983. The correlates of entrepreneurship in three types of firms. Manage. Sci., 29: 770-791. DOI: $10.1287 / \mathrm{mnsc} .29 .7 .770$

Morris, M.H. and G.W. Paul, 1987. The relationship between entrepreneurship and marketing in established firms. J. Bus. Ventur., 2: 247-259. DOI: 10.1016/0883-9026(87)90012-7

Nahapiet, J., and S. Ghoshal, 1998. Social capital, intellectual capital, and the organizational advantage. Acad. Manage. Rev., 23: 242-266. DOI: $10.2307 / 259373$

Rauch, A., J. Wiklund, G.T. Lumpkin, and M. Frese, 2009. Entrepreneurial orientation and business performance: An assessment of past research and suggestions for the future. Entrepreneurship: Theory Practice, 33: 761-787. DOI: 10.1111/j.1540-6520.2009.00308.x

Roy, S., K. Sivakumar, and I.F. Wilkinson, 2004. Innovation generation in supply chain relationships: A conceptual model and research propositions. J. Acad. Market. Sci., 32: 61-79. DOI: $10.1177 / 0092070303255470$

Runyan, R.C., P. Huddleston, and J.L. Swinney, 2007. A resource-based view of the small firm: Using a qualitative approach to uncover small firm resources. Q. Market Res.: Int. J., 10: 390-402. DOI: $10.1108 / 13522750710819720$
Salavou, H. and S. Lioukas, 2003. Radical product innovations in SMEs: The dominance of entrepreneurial orientation. Creativity Innovat. Manage., 12: 94-108. DOI: 10.1111/14678691.00272

Schumpeter, J.A., 1982. The Theory of Economic Development. Transaction Publishers, 244 pages, ISBN-10: 0878556982.

Soriano, D.R. and S.R. Dobon, 2009. Linking globalization of entrepreneurship in small organizations. Small Bus. Econ., 32: 233-239. DOI: $10.1007 / \mathrm{s} 11187-008-9155-5$

Stam, W., and T. Elfring, 2006. Entrepreneurial orientation and new venture performance: The mediating effect of network strategies. Best Conference Paper, Academy of Management, K1K6. http://www.bm.ust.hk/mgmt/staff/wstam.html

Tan, C.N.L., 2011. Knowledge management acceptance: Success factors amongst small and medium-size enterprises. Am. J. Econ. Bus. Admin., 3: 73-80. DOI: 10.3844/ajebasp.2011.73.80

Tang, J., Z. Tang, L.D. Marino, Y. Zhang, and Q. Li, 2008. Exploring an inverted U-shape relationship between entrepreneurial orientation and performance in Chinese ventures. Entrepreneurship Theory Practice, 32: 219-239. DOI: 10.1111/j.1540-6520.2007.00223.X

Tang, J., Z. Tang, Y. Zhang, and Q. Li, 2007. The impact of entrepreneurial orientation and ownership type on firm performance in the emerging region of China, J. Dev. Entrepreneurship, 12: 383-397. DOI: $10.1142 / \mathrm{S} 1084946707000733$

Tsai, W., 2000. Social capital, strategic relatedness and the formation of intraorganizational linkages. Strategic Manage. J., 21: 925-939. DOI: 10.1002/1097-0266(200009)21:9<925::AIDSMJ129>3.0.CO;2-I

Wiklund, J. and D. Shepherd, 2005. Entrepreneurial orientation and small business: A configurational approach. J. Bus. Ventur., 20: 71-91. DOI: 10.1016/j.jbusvent.2004.01.001

Wiklund, J., 1999. The sustainability of the entrepreneurial orientation-performance relationship. Entrepreneurship: Theory Practice, 24: 37-48. http://www.entrepreneur.com/tradejournals/article/ 59700620.html

Zahra, S.A. and J.G. Covin, 1995. Contextual influence on the corporate entrepreneurship performance relationship: A longitudinal analysis. J. Bus. Ventur., 10: 43-58. DOI: 10.1016/08839026(94)00004-E 
Zahra, S.A., 1991. Predictors and financial outcomes of corporate entrepreneurship: An explorative study. J. Bus. Ventur., 6: 259 -285. DOI: 10.1016/08839026(91)90019-A
Zahra, S.A., 1996. Technology strategy and new venture performance: A study of corporatesponsored and independent biotechnology ventures. J. Bus. Ventur., 11: 289-321. DOI: 10.1016/0883-9026(95)00128-X 